\title{
Reduced susceptibility of thin Pseudomonas aeruginosa biofilms to hydrogen peroxide and monochloramine
}

\author{
W. L. Cochran', G. A. McFeters ${ }^{1}$ and P. S. Stewart ${ }^{2}$ \\ Departments of ${ }^{1}$ Microbiology and ${ }^{2}$ Chemical Engineering, Center for Biofilm Engineering, Montana State University, \\ Bozeman, MT, USA \\ 7084/02/99: received 19 February 1999 and accepted 23 April 1999
}

W. L. cochran, G. A. McFeters and P. S. Stewart. 2000. Pseudomonas aeruginosa attached to alginate gel beads in sparse, thin biofilms exhibited reduced susceptibility to monochloramine and hydrogen peroxide compared with planktonic cells of the same micro-organism. Disinfection rate coefficients for planktonic bacteria averaged $0.551 \mathrm{mg}^{-1} \mathrm{~min}^{-1}$ for monochloramine and $3 \cdot 1 \times 10^{-4} 1 \mathrm{mg}^{-1} \mathrm{~min}^{-1}$ for hydrogen peroxide. The corresponding values for 24 -h-old biofilm cells were $0.291 \mathrm{mg} \mathrm{min}^{-1}$ and $9 \cdot 2 \times 10^{-5} 1 \mathrm{mg}^{-1} \mathrm{~min}^{-1}$ for monochloramine and hydrogen peroxide, respectively.

Several pieces of evidence support the interpretation that the reduced susceptibility of biofilm was not due simply to inadequate delivery of the antimicrobial agent to the local environment of the attached cells. No correlation between biofilm susceptibility and biofilm initial areal cell density was observed. Rapid delivery of hydrogen peroxide to the attachment surface, and subsequently to the interior, of the alginate gel beads was visualized by a direct experimental technique. Theoretical analysis of unsteady diffusion and diffusion-reaction interactions also argued against any significant delay or barrier to antimicrobial or oxygen delivery. It was hypothesized that new genes are expressed when bacteria attach to a surface and begin to form a biofilm and that some of the resulting gene products reduce the susceptibility of the cell to antimicrobial agents including oxidative biocides such as monochloramine and hydrogen peroxide.

\section{INTRODUCTION}

When micro-organisms grow attached to a surface in the form of a biofilm they exhibit remarkable resistance to all types of antimicrobial challenge when compared with the same micro-organisms grown in suspended cultures (Gilbert and Brown 1995). This phenomenon of reduced biofilm susceptibility explains the chronic nature of biofilm infections and thwarts efforts to control biofouling in a wide variety of industrial settings (Costerton, Marrie and Cheng 1985). The fundamental physical, chemical and biological mechanisms by which biofilm micro-organisms escape killing by biocides and antibiotics are still incompletely understood.

We distinguish three types of hypothesized mechanisms of

Correspondence to: Philip S. Stemart, Department of Chemical Engineering, Center for Biofilm Engineering, 366 EPS Building, Montana State

University, Bozeman, MT 59717, USA (e-mail:

phil_s@erc.montana.edu). reduced biofilm susceptibility to antimicrobial agents. The first of these is failure of the antimicrobial agent to penetrate the full depth of the biofilm. This does indeed occur in certain instances (de Beer, Srinivasan and Stewart 1994; Chen and Stewart 1996; Xu, Stewart and Chen 1996; Liu et al. 1998; Stewart, Grab and Diemer 1998). The reaction-diffusion interaction underlying poor penetration is now well enough understood that it can be mathematically modelled (Stewart and Raquepas 1995; Chen and Stewart 1996; Dibdin et al. 1996; Stewart 1996). Penetration failure is most viable as a resistance mechanism when dealing with thick biofilms and highly reactive antimicrobials.

A second mechanism of biofilm reduced susceptibility requires that at least some of the cells within a biofilm experience a nutrient limitation that causes them to enter a slowgrowing or starved state (Brown, Allison and Gilbert 1988). Slow or non-growing cells have been shown to be less susceptible to a variety of antimicrobial agents when compared 
with cells grown in rich media at high specific growth rates. There is considerable experimental support for this mechanism (Gilbert and Brown 1995) and also for striking spatial heterogeneity in the physiological status of bacteria within relatively thick $(100 \mu \mathrm{m})$ biofilms (Wentland et al. 1996; Xu et al. 1998).

The third mechanism of reduced biofilm susceptibility, which is more speculative than the preceding hypotheses, is that at least some of the cells in a biofilm adopt a distinct, and relatively protected, biofilm phenotype. This phenotype is not the result of a nutrient limitation. Whereas the first two mechanisms outlined above both involve a transport limitation, in the first case for the antimicrobial agent itself and in the second case for a nutrient, there is no requirement for any transport limitation in the 'resistant biofilm phenotype' hypothesis. The practical importance of this mechanism, should it prove true, is profound because it implies that reduced susceptibility of biofilm is genetically programmed. This would open the door to many novel approaches to biofilm control. It is the possibility of an intrinsically distinct biofilm phenotype that motivated the work reported in this paper.

A good experimental demonstration of the existence of a resistant biofilm phenotype requires that transport phenomena be eliminated as factors influencing biofilm susceptibility. We have addressed this requirement by using a model biofilm system in which bacteria were attached in sparse, thin films to the surface of highly hydrated alginate gel beads. These gel beads can be maintained in an aqueous suspension with stirring. Their well-defined spherical geometry allows mass transfer characteristics between the bulk fluid and the surface of the gel bead (where bacteria are located) to be accurately calculated. Because the gel beads are readily permeated by solutes, antimicrobial agents can be delivered to all aspects of the attached cell.

The experimental aim of this study was to evaluate the efficacy of two antimicrobial agents on thin biofilms grown in a system where biocide mass transport was not an issue. The antimicrobial effects of monochloramine and hydrogen peroxide were assessed in this novel biofilm system by comparing disinfection rates of planktonic and attached cells.

\section{MATERIALS AND METHODS}

\section{Bacterial strains, culture and enumeration}

All disinfection experiments used Pseudomonas aeruginosa PAO1 (Holloway 1955). Strains were cultured in modified R2A broth (American Public Health Association et al. 1995) without $\mathrm{K}_{2} \mathrm{HPO}_{4}$ and starch, and with the addition of $3 \cdot 4 \mathrm{mmol} \mathrm{l}^{-1} \mathrm{CaCl}_{2} \cdot 2 \mathrm{H}_{2} \mathrm{O}$. Enumeration of bacteria was performed by serial dilution in phosphate-buffered saline (PBS; pH 7.5) (US Food and Drug Administration 1984) followed by drop plating 10- $\mu$ l drops (Miles and Misra 1938; Hoben and Somasegaran 1982) onto R2A plates (Difco Laboratories, Detroit, MI).

\section{GFP expressing Ps. aeruginosa}

To visualize bacterial cell distribution on the surface of alginate beads, a plasmid that constitutively expressed the green fluorescent protein (GFP) was introduced into Ps. aeruginosa PAO1. The gene for the GFP containing the mut 2 mutation (Cormick, Valdivia and Falkow 1996) was amplified from plasmid pBC $g f p$ using PCR (Matthysse et al. 1996). The PCR primers used in the amplification were GFPSal3-5'GC GCGTCGACAGGAGAAGAAAAAATGAGTAAACCA GAAGA 3' and GFPHind4-5' GTACCTGGAATTCTACGAAGCTTATTTGTATAGTTCATCC 3'. The PCR product was digested with SalI and HindIII, and ligated into pUC19. The XbaI and HindIII fragment from pUC18, containing the gfpmut2, was then ligated into vector pMF36 (Franklin and Ohman 1993) behind the strong trc promoter, forming plasmid pMF230. Since pMF36 contains the oriT site and the stable replication fragment, it was mobilized into $P$ s. aeruginosa by triparental mating and was stably maintained. pMF36 does not contain lacI, resulting in constitutive expression of $g f p$ from the $\operatorname{trc}$ promoter.

\section{Alginate gel beads}

The method of Smidsrød and Skjåk-Bræk (1990) was used to prepare gel beads. A $2 \%(\mathrm{w} / \mathrm{v})$ sodium alginate solution was autoclaved for $30 \mathrm{~min}$ and then mixed on a stir plate overnight. Sterile 2-mm diameter beads were formed by dropping liquid alginate solution into stirred $1 \%(\mathrm{w} / \mathrm{v})$ sterile $\mathrm{CaCl}_{2} \cdot 2 \mathrm{H}_{2} \mathrm{O}$.

\section{Biofilm formation}

An overnight culture of Ps. aeruginosa was diluted to $10^{6}$ colony forming units (c.f.u.) $\mathrm{ml}^{-1}$ in $500 \mathrm{ml}$ of R2A in a 1500 $\mathrm{ml}$ beaker containing approximately 3000 alginate beads. Cells were allowed to attach to the beads for up to $2 \mathrm{~h}$ at room temperature with continuous stirring. The medium was decanted and replaced with sterile broth. Beads were incubated at room temperature for various time intervals from 3.25 to $72 \mathrm{~h}$. Spent medium was removed and sterile R2A was added approximately every $4-8 \mathrm{~h}$ to maintain nutrient replete growth conditions. Before disinfection assays, beads were rinsed three times in $\mathrm{R} 2 \mathrm{~A}$ and incubated for an additional 3-4h to ensure the absence of stationary phase cells. 


\section{Epifluorescence microscopy}

GFP containing biofilms were grown for 24 and $48 \mathrm{~h}$ as described above. Micrographs of cells attached to alginate beads were taken using a Nikon optiphot microscope with a B2A epifluorescence filter, a Nikon N70 camera and Kodak Tmax 400 black and white film.

\section{Preparation of disinfectants}

Monochloramine solution was prepared as previously described by Chen, Griebe and Characklis (1993) and hydrogen peroxide solutions were prepared by diluting Hach unstabilized hydrogen peroxide (30\%) (ACS grade cat \# 144-11). Both monochloramine and hydrogen peroxide were titrated prior to each experiment to determine their concentrations. Monochloramine was titrated using a Hach amperometric titrator (Hach, Loveland, CO, USA). To determine hydrogen peroxide concentration, the method of Klothoff and Sandell (1952) was modified by titrating to a colourless endpoint using standardized $0 \cdot 1 \mathrm{eq}^{-1}$ sodium thiosulphate $\left(\mathrm{Na}_{2} \mathrm{~S}_{2} \mathrm{O}_{3}\right)$.

\section{Planktonic disinfection assay}

An overnight culture of Ps. aeruginos $a$ was sub-cultured into fresh R2A to a final cell concentration between $10^{7}$ and $10^{8}$ c.f.u. $\mathrm{ml}^{-1}$ and incubated for $4 \mathrm{~h}$. The exponentially growing culture of $P$ s. aeruginos $a$ was homogenized with a tissue homogenizer for one minute on ice. The cells were then diluted to $10^{6}$ c.f.u. $\mathrm{ml}^{-1}$ in phosphate-buffered water (pH7) (PBW) (American Public Health Association etal. 1995). Monochloramine stock solution was added to the PBW to attain a final concentration of $2 \mathrm{mg} \mathrm{1^{-1 }}$. Cells were sampled at timed intervals over a 10 -min period from the start of the experiment. Cells were removed from the monochloramine and diluted into PBS containing $\mathrm{Na}_{2} \mathrm{~S}_{2} \mathrm{O}_{3}\left(1 \mathrm{mmol} \mathrm{l}^{-1}\right.$ final concentration) to neutralize the monochloramine. Total remaining chlorine in the reaction vessel was determined using the Hach amperometric titrator. Disinfection experiments were also performed with $600 \mathrm{mg}^{-1}$ hydrogen peroxide. Cells were sampled every $10 \mathrm{~min}$ for $1 \mathrm{~h}$. The reaction was stopped by using $4 \cdot 12 \mathrm{mmol} \mathrm{l}^{-1}$, final concentration, of $\mathrm{Na}_{2} \mathrm{~S}_{2} \mathrm{O}_{3}$ in PBS. Final hydrogen peroxide concentrations were determined by titration with $\mathrm{Na}_{2} \mathrm{~S}_{2} \mathrm{O}_{3}$ as described above.

As controls, planktonic cells were sub-cultured in PBW $\left(10^{6}\right.$ c.f.u. $\left.\mathrm{ml}^{-1}\right)$ without the addition of an antimicrobial agent and sampled at the start and end of the disinfection assay. For all disinfection experiments, cells were serially diluted in PBS and enumerated by the drop plate method, as described above.

\section{Biofilm disinfection assays}

Alginate beads with attached cells were removed from the R2A, rinsed three times with sterile medium, and suspended in $1000 \mathrm{ml}$ of PBW. While mixing beads on a magnetic stir plate, monochloramine was added to reach a final concentration of $2 \mathrm{mg}^{-1}$. Between 30 and 50 beads were removed with a wide-mouth 5 -ml pipette tip at timed intervals over a $10-$ min period and neutralized with $\mathrm{Na}_{2} \mathrm{~S}_{2} \mathrm{O}_{3}$ ( $1 \mathrm{mmol} \mathrm{l}^{-1}$ final concentration). The supernatant was decanted from the bead sample and $3 \mathrm{ml}$ of citrate buffer $(\mathrm{pH} 7 \cdot 5)(8 \mathrm{~g}$ of sodium citrate in 11 of PBS) added to facilitate bead dissolution. Beads were blended on ice using a tissue homogenizer for $1 \mathrm{~min}$ and refrigerated for up to $2 \mathrm{~h}$. Total remaining chlorine in the reaction vessel was titrated as described above. Biofilm disinfection studies were also performed with hydrogen peroxide. This disinfectant was added to a final concentration of $600 \mathrm{mg} \mathrm{l}^{-1}$, and beads were sampled every $10 \mathrm{~min}$ for $1 \mathrm{~h}$. Supernatant was decanted immediately after bead removal from the reactor and beads were neutralized with $3 \mathrm{ml}$ of $6.32 \mu \mathrm{mol} 1^{-1} \mathrm{Na}_{2} \mathrm{~S}_{2} \mathrm{O}_{3}$ in citrate buffer. Beads were homogenized on ice and stored at $4{ }^{\circ} \mathrm{C}$ for up to $2 \mathrm{~h}$.

As controls, attached cells were diluted in PBW as described above, but without the addition of an antimicrobial agent. These were sampled at the beginning and the end of the assay. In addition, disinfection experiments were repeated with sterile beads to ensure that beads did not significantly degrade monochloramine or hydrogen peroxide. Homogenized beads were diluted in PBS and enumerated.

\section{Biofilm formation and disinfection on glass slides}

Ps. aeruginosa biofilms were grown on glass slides in a biofilm apparatus described by Cargill et al. (1992). Biofilms were grown for $24 \mathrm{~h}$ in conditions similar to the bead biofilms, in that spent medium was removed every $4-8 \mathrm{~h}$ to maintain nutrient replete growth conditions. Four hours before disinfection assays, slides were placed into fresh R2A. Disinfection of the glass slides occurred in a clean sterile jar to eliminate the oxidant demand associated with excessive organic matter. Sample slides were removed at timed intervals and placed into PBW containing sodium $\mathrm{Na}_{2} \mathrm{~S}_{2} \mathrm{O}_{3}$ to neutralize the biocide. Slides were then scraped into PBS and cells were homogenized and enumerated on R2A plates.

\section{Disinfection rate coefficient values}

The model used to interpret disinfection rates was

$\mathrm{d} X / \mathrm{d} t=-k_{\mathrm{b}} C X$

where the change in areal cell density with time is related to the disinfection coefficient, $k_{\mathrm{b}}$, biocide concentration, $C$, and viable cell density, $X$. Raw disinfection rates were determined by using the least squares method to calculate a regression line through the data consisting of the natural logarithm of c.f.u. $\mathrm{cm}^{-2}$ vs time (units of $\mathrm{min}^{-1}$ ). A slope with its standard 
error was calculated, where the slope was the disinfection rate for that experiment. The disinfection rate coefficient was determined by dividing raw disinfection rates by the average biocide concentration (units $\mathrm{mg}^{-1}$ ) to normalize against variations in disinfectant concentration. This coefficient has units of $1 \mathrm{mg}^{-1} \mathrm{~min}^{-1}$.

\section{Statistical analysis}

All statistical analyses were performed using Minitab Release 11·12 (Minitab Inc., State College, PA, USA). $P$-values were calculated using the null hypothesis that the two sets of disinfection rate coefficients were the same. A $P$-value less than 0.05 indicates that the two sets are statistically different.

\section{Observed penetration of hydrogen peroxide into alginate gel beads}

Mass transport of hydrogen peroxide into gel beads was visualized experimentally. Beads with 24 -h-old biofilms were incubated with hydrogen peroxide colour indicators used in hydrogen peroxide titration, as described above, for $15 \mathrm{~min}$. Colour indicator solution was removed and $600 \mathrm{mg} \mathrm{l}^{-1}$ hydrogen peroxide was added to the beads. Images were digitally captured at timed intervals to show the diffusion of hydrogen peroxide into the beads. A COHU ${ }^{\circledR}$ camera (Cohu Inc., San Diego, CA, USA; model no: 2222-1040/0000) and Flashpoint $^{\circledR}$ frame grabber (Integral Technologies Inc., Indianapolis, IN, USA) connected to a computer with ImagePro 3.0 (Media Cybernetics, Silver Spring, MD, USA) were used.

\section{Mass transport analysis}

To address how effectively solutes (biocides or nutrients) added to the bulk solution were transported to the bead surface, mass transport limitation was theoretically analysed. This was done by calculating the time required to attain $90 \%$ of the bulk fluid concentration at the bead surface or, in the case of a sustained neutralization or utilization reaction by the microbial cells, the concentration of biocide at the bead surface that was attained at steady state.

The unsteady diffusion of a non-reacting solute from the bulk fluid into the permeable gel bead was addressed first. The diffusion equation in spherical co-ordinates was solved subject to a matching flux boundary condition and an initial condition imposing zero concentration throughout the bead. The solution to this problem was given by Crank (1956).

Parameter values required for these calculations include the bead dimension, effective diffusion coefficients, and an external mass transfer coefficient. A bead radius of $0.1 \mathrm{~cm}$ was used. Diffusion coefficients in gel beads were taken as 90\% (Westrin and Axelsson 1991) of the value in water at $25^{\circ} \mathrm{C}$ as estimated from the Wilke-Chang correlation (Perry and Chilton 1973). The effective diffusion coefficient of monochloramine in the gel bead calculated in this way was $1.7 \times 10^{-5} \mathrm{~cm}^{2} \mathrm{~s}^{-1}$ and for hydrogen peroxide it was $1.3 \times 10^{-5} \mathrm{~cm}^{2} \mathrm{~s}^{-1}$. The mass transfer coefficient describing transport between the bulk fluid and the bead surface was estimated by Xu et al. (1996), using an established correlation, to be $5 \times 10^{-3} \mathrm{~cm} \mathrm{~s}^{-1}$.

Bacteria neutralize monochloramine and hydrogen peroxide (Brown et al. 1995; Sanderson and Stewart 1997) and utilize nutrient substrates. Bacteria attached to a substratum can reduce the local concentration of these molecules at the bead surface below the bulk fluid concentration. This problem can be mathematically analysed by equating the flux due to reaction with the flux determined by the external mass transfer coefficient for the system. From Sanderson and Stewart (1997), the order of magnitude of Ps. aeruginosa capacity for reaction with monochloramine was $5 \times 10^{-14} \mathrm{mg} \mathrm{s}^{-1}$ cell $^{-1}$. Taking the highest cell density encountered in the present experiments of $4 \times 10^{5}$ c.f.u. $\mathrm{cm}^{-2}$, the maximum flux due to reaction was approximately $2 \times 10^{-8} \mathrm{mg} \mathrm{cm}^{-2}$ $\mathrm{s}^{-1}$. At steady state this must exactly match the flux supplied by transport from the bulk fluid to the surface and the concentration at the bead surface can be solved. An analogous calculation was performed for hydrogen peroxide using the induced level of catalase activity reported by Brown et al. (1995), equivalent to approximately $2 \times 10^{-10} \mathrm{mg} \mathrm{s}^{-1} \mathrm{cell}^{-1}$, and for oxygen using $1 \times 10^{-13} \mathrm{mg} \mathrm{s}^{-1}$ cell $^{-1}$ (Bakke et al. 1984).

\section{RESULTS}

\section{Disinfection rate coefficients}

Planktonic disinfection rate coefficients for monochloramine experiments all fell within a tight cluster of values ranging from 0.40 to $0.571 \mathrm{mg}^{-1} \mathrm{~min}^{-1}$ (Fig. 1). Disinfection rate coefficients were calculated by dividing the raw disinfection rates $\left(\mathrm{min}^{-1}\right)$ by the average biocide concentration $\left(\mathrm{mg} \mathrm{l}^{-1}\right)$. This normalized the data against any experiment-to-experiment variation in the biocide concentration. Disinfection rate coefficient values were significantly higher for planktonic cells than they were for 20-h-old and older biofilms, for which disinfection rate coefficient values fell into a range of $0 \cdot 19$ $0.231 \mathrm{mg}^{-1} \mathrm{~min}^{-1}$. $P$-values comparing planktonic disinfection rate coefficient values with 20 -h-old and older biofilms were all less than 0.008 (Table 1).

There was no correlation between initial cell density of the biofilm and disinfection rate coefficient (Fig. 2). The areal cell density of the gel bead-attached biofilms prior to treatment was relatively low averaging $3.5 \pm 0.58 \log$ c.f.u. $\mathrm{cm}^{-2}$. The $P$-value for the regression line fit to the data in Fig. 2 was $0 \cdot 84$, indicating that there was no significant dependence 


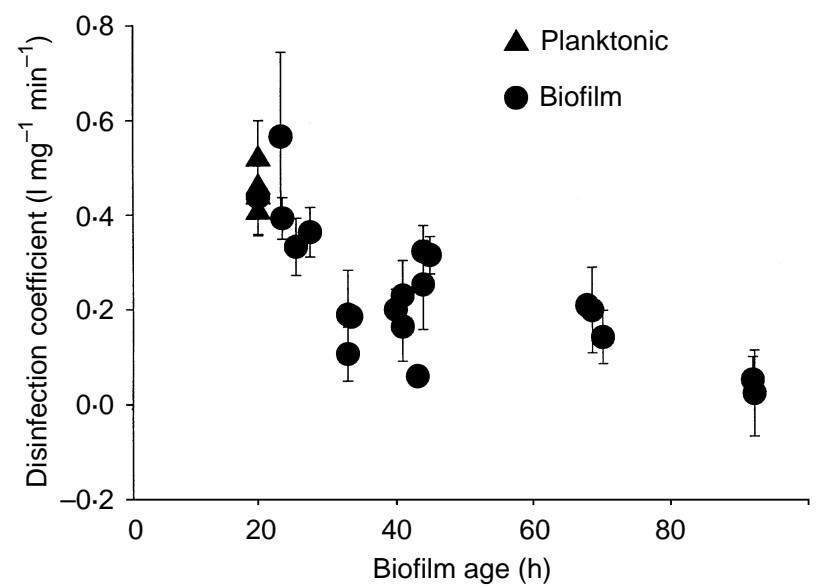

Fig. 1 Disinfection rate coefficients of planktonic and biofilm $P s$. aeruginosa cells treated with $2 \mathrm{mg}^{-1}$ of monochloramine. Error bars represent standard errors

Table $1 P$-values for comparison of planktonic and biofilm susceptibility

\begin{tabular}{|c|c|c|c|c|}
\hline & \multicolumn{4}{|c|}{ Biofilm age (h) } \\
\hline & $\begin{array}{l}20 \\
n=3^{*}\end{array}$ & $\begin{array}{l}24 \\
n=3^{*}, \dagger\end{array}$ & $\begin{array}{l}48 \\
n=3^{*}, 2 \dagger\end{array}$ & $\begin{array}{l}72 \\
n=2\end{array}$ \\
\hline \multicolumn{5}{|l|}{ Biocide } \\
\hline MCA & $0 \cdot 0002$ & $0 \cdot 0018$ & $0 \cdot 0003$ & $0 \cdot 0004$ \\
\hline $\mathrm{H}_{2} \mathrm{O}_{2}$ & & $0 \cdot 015$ & $0 \cdot 019$ & \\
\hline
\end{tabular}

$n$ is the number of replicates for biocide experiments.

* Replicate number for monochloramine experiments.

$\uparrow$ Replicate number for hydrogen peroxide experiments.

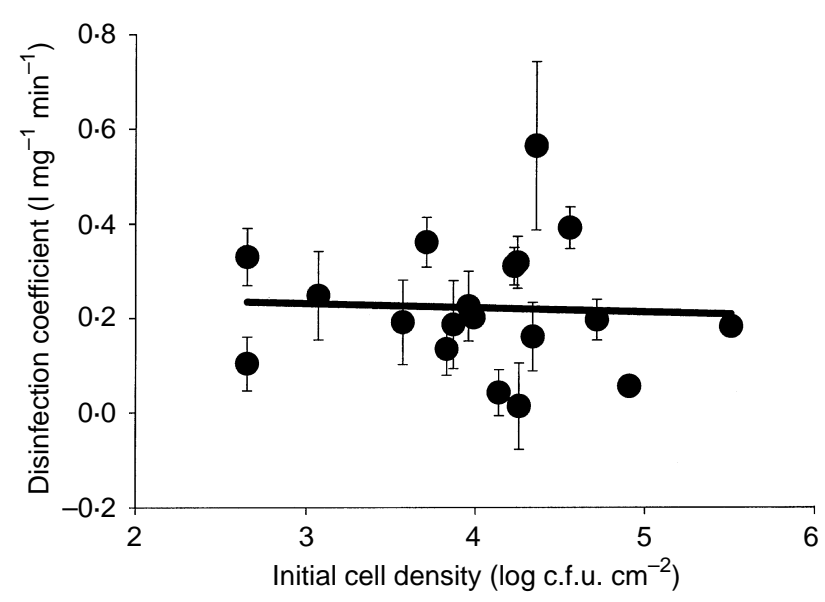

Fig. 2 Influence of initial cell density on disinfection efficacy. Error bars represent standard errors of biofilm susceptibility to monochloramine on the initial cell areal density.

Disinfection with hydrogen peroxide (Fig. 3) yielded results qualitatively similar to the monochloramine experiments. Planktonic cell disinfection rate coefficients ranged from $2 \cdot 3 \times 10^{-4}$ to $4 \cdot 0 \times 10^{-4} \mathrm{l} \mathrm{mg}^{-1} \mathrm{~min}^{-1}$ and biofilm disinfection rate coefficients ranged from $8.8 \times 10^{-5}$ to $9 \cdot 7 \times 10^{-5} 1 \mathrm{mg}^{-1} \mathrm{~min}^{-1}$. The planktonic disinfection rate coefficient values were significantly greater than the biofilm disinfection rate coefficient values with $P$-values less than 0.05 for these comparisons (Table 1 ). As with the monochloramine data, there was no correlation between initial density of biofilm cells and disinfection rate coefficient values when using hydrogen peroxide $(P=0 \cdot 43)$.

Additional disinfection studies with monochloramine and hydrogen peroxide were performed using biofilms grown on glass slides instead of on alginate gel beads. Biofilm growth on glass slides resulted in thicker biofilms than biofilms grown on alginate beads. The initial areal cell density of glass slide biofilms averaged of $7 \cdot 6 \pm 0 \cdot 27 \mathrm{log}$ c.f.u. $\mathrm{cm}^{-2}$. These biofilms were also clearly less susceptible to both disinfectants when compared with planktonic cells (Fig. 4). Disinfection rate coefficient values for 24-h biofilms ranged from $5 \cdot 5 \times 10^{-2}$ to $0.201 \mathrm{mg}^{-1} \mathrm{~min}^{-1}$ for monochloramine and from $3.4 \times 10^{-5}$ to $8 \cdot 0 \times 10^{-5} 1 \mathrm{mg}^{-1} \mathrm{~min}^{-1}$ for hydrogen peroxide. These biofilm disinfection rate coefficient values were statistically significantly lower than values for planktonic cells $(P<0 \cdot 01)$.

\section{Cell attachment and distribution on alginate beads}

GFP expressing $P$ s. aeruginos $a$ clearly showed the distribution of attached cells on alginate beads (Fig. 5). Beads with cells attached for $24 \mathrm{~h}$ were sparsely populated. Much of the bead

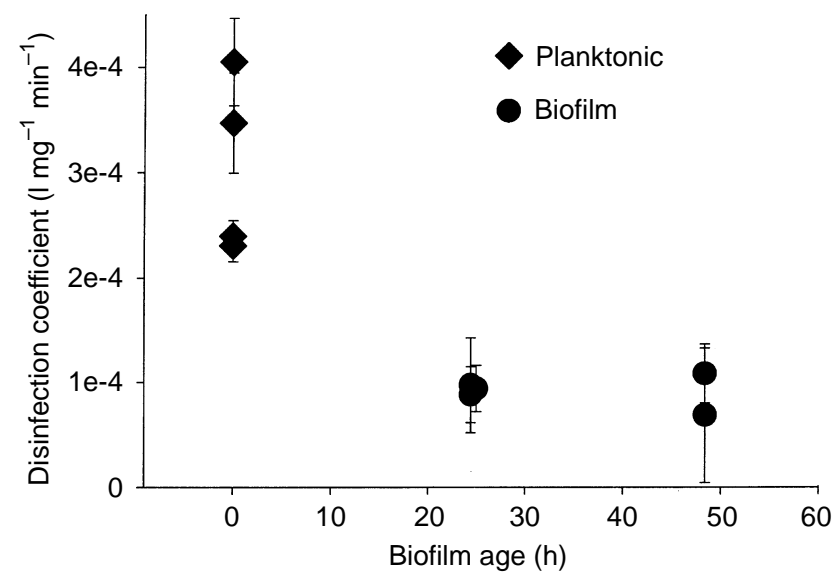

Fig. 3 Disinfection rate coefficients of planktonic and biofilm $P$ s. aeruginos a cells treated with $600 \mathrm{mg} \mathrm{l}^{-1}$ of hydrogen peroxide. Error bars represent standard errors 


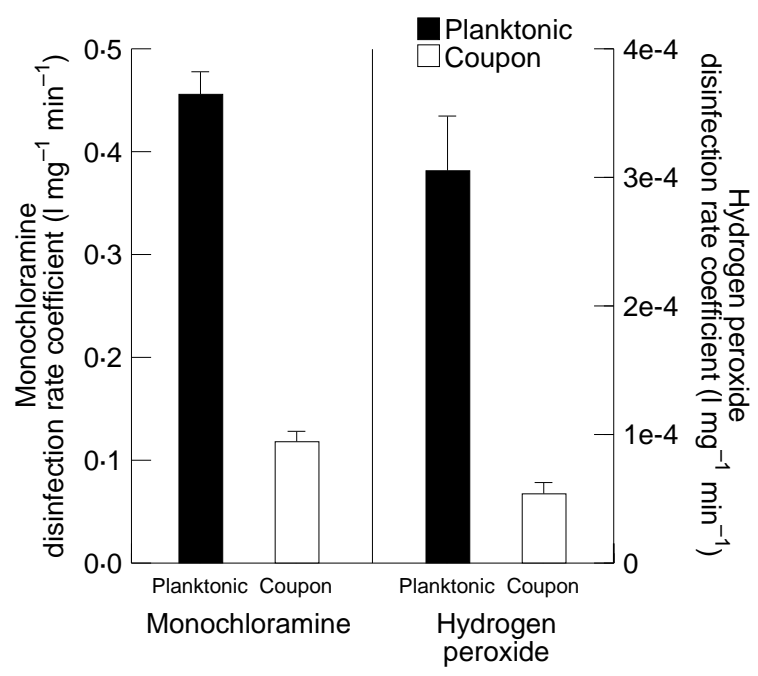

Fig. 4 Mean disinfection rate coefficients obtained from biofilms grown on glass slides exposed to either $2 \mathrm{mg} \mathrm{l}^{-1}$ of monochloramine or $600 \mathrm{mg} \mathrm{l}^{-1}$ of hydrogen peroxide. Error bars represent

standard error of the means. Each coupon experiment was repeated five times to calculate the mean disinfection rate coefficient

area observed contain few or no cells. The cells that were observed appeared to be attached as single cells or in small microcolonies. Colonies were uncommon. Although, 48-hold biofilms were slightly more populated, the overall trend of sparsely distributed cells was the same as that observed for the 24-h-old biofilms.

\section{Hydrogen peroxide penetration in alginate gel beads}

Hydrogen peroxide was shown to penetrate cell-covered gel beads rapidly by a direct visualization technique. Gel beads incubated in hydrogen peroxide titration reagents turned a characteristic blue-black colour upon the addition of hydrogen peroxide. The rapid appearance of this colour at the surface of the gel beads and in progressively deeper layers of the gel bead could be seen by examination with low power magnification (Fig. 6). Full penetration was observed within $2.5 \mathrm{~min}$ after the addition of hydrogen peroxide (Fig. 6c). When the neutralizing agent sodium thiosulphate was added to the beads, the bead colour turned back to a translucent white from the outside to the inside as the neutralizer diffused through the bead. Within $5 \mathrm{~min}$ after the sodium thiosulphate addition, hydrogen peroxide in the gel bead had been completely neutralized, as indicated by a uniform white colour throughout the bead (Fig. 6f).

\section{Theoretical analysis of mass transport}

Penetration of biocides to the bead surface was not significantly hindered by mass transport according to theoretical

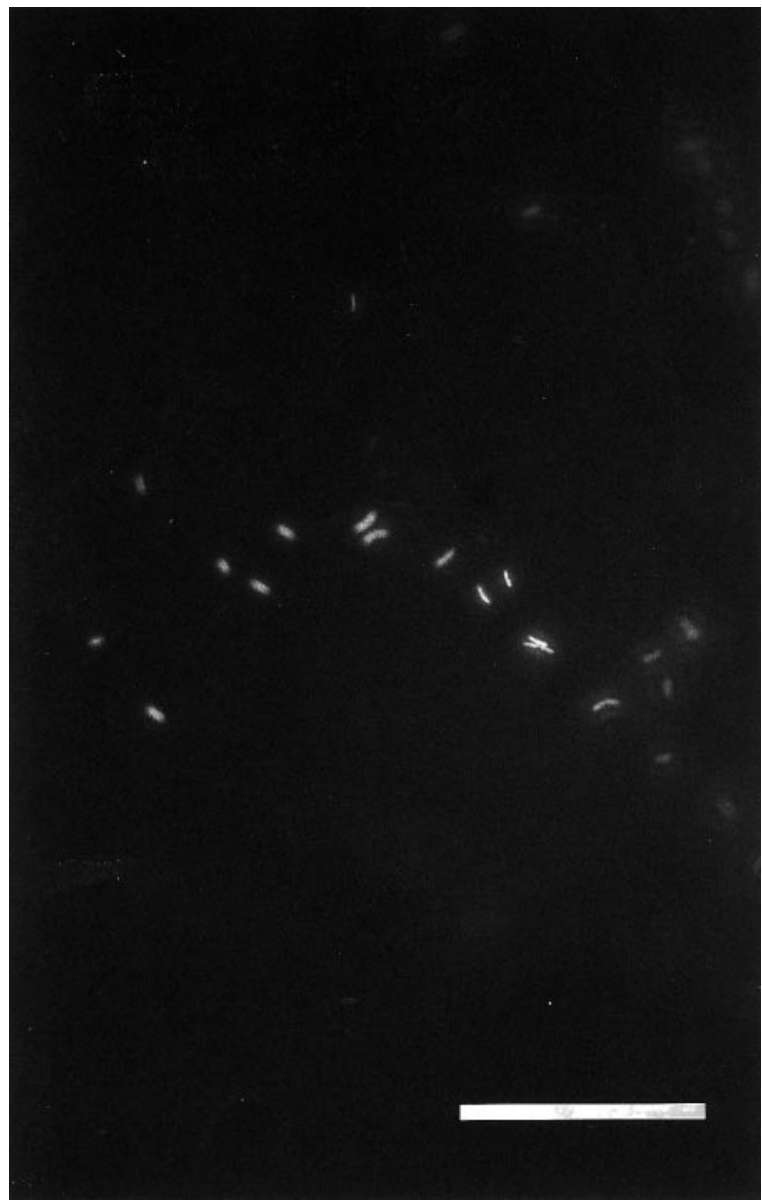

Fig. 5 Use of GFP to detect Ps. aeruginosa biofilms on alginate gel beads. Epifluorescence of 24-h-old biofilms showed that cell distribution consisted mostly of single cells and small microcolonies. Bar represents $5 \mu \mathrm{m}$

calculations. An unsteady diffusion model predicted that after $33 \mathrm{~s}$ the monochloramine concentration at the bead surface would be $95 \%$ of the bulk fluid concentration. This was relatively rapid when compared with the duration of the disinfection experiments of $6-10 \mathrm{~min}$. For hydrogen peroxide the calculated time to reach $95 \%$ of the bulk fluid concentration at the bead surface was $44 \mathrm{~s}$. Again, this represented only a brief delay compared with the hour-long treatment period. When a biocide-neutralizing reaction was taken into account, the steady-state bead surface concentration was predicted to be at least $99 \cdot 8 \%$ of the bulk fluid concentration for monochloramine and at least $96 \%$ of the bulk fluid concentration for hydrogen peroxide. In summary, theoretical analysis of biocide transport suggests that transport limitation can explain no more than a few percent of the observed reduction in susceptibility of biofilm bacteria.

The calculated oxygen concentration at the bead surface was greater than $99 \%$ of the bulk fluid oxygen concentration. 

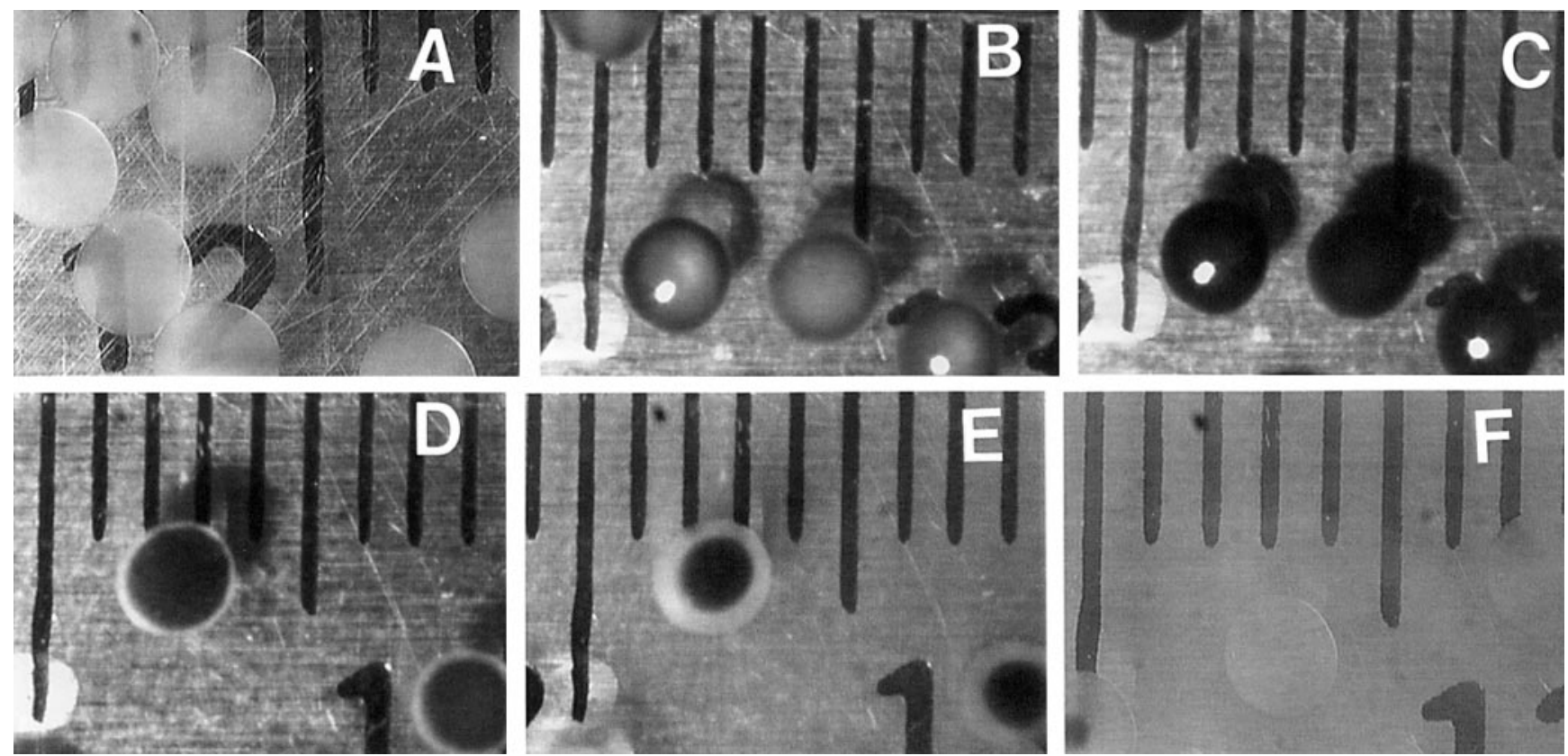

Fig. 6 Diffusion of hydrogen peroxide into 24-h gel bead biofilms. Beads were incubated in hydrogen peroxide colour indicators for $15 \mathrm{~min} .600 \mathrm{mg} \mathrm{l}^{-1}$ of hydrogen peroxide was then added. Photographs were taken at $0 \mathrm{~s}(\mathrm{~A}), 10 \mathrm{~s}(\mathrm{~B})$ and $150 \mathrm{~s}(\mathrm{C})$. As hydrogen peroxide diffused through the bead, the bead turned black. Sodium thiosulphate, $0 \cdot 1 \mathrm{eq} 1^{-1}$ was added to the beads to show the diffusion of the neutralizer into the gel beads. Photographs shown were taken at $10 \mathrm{~s}$ (D), $120 \mathrm{~s}$ (E) and $290 \mathrm{~s}$ (F) after the addition. As sodium thiosulphate diffused through the bead, the hydrogen peroxide was neutralized and bead turned back to white

Local anaerobic conditions in the biofilm can therefore not be anticipated.

\section{DISCUSSION}

\section{Reduced susceptibility of biofilm cells}

Ps. aeruginosa cells attached to alginate gel beads were significantly less susceptible to disinfection by monochloramine and hydrogen peroxide than were planktonic cells of the same micro-organism. The observed resistance increased with increasing biofilm age, at least for monochloramine. Reduced susceptibility could not be detected with statistical significance for biofilm cells less than 13-h-old but was clearly established by the time cells had been attached for $24 \mathrm{~h}$.

\section{Reduced susceptibility is not a transport artifact}

Several pieces of evidence support the interpretation that reduced susceptibility of biofilm was not simply due to inadequate delivery of the antimicrobial agent to the local environment of the attached cells. Solute penetration into a biofilm depends critically on the biofilm thickness. If antimicrobial penetration was a governing factor, one would expect to see an inverse correlation between biofilm susceptibility and biofilm areal cell density. No such correlation was observed
(Fig. 2). Direct microscopic observation of cells attached to the gel beads confirms that cells are distributed in a sparse, thin layer (Fig. 5). Visualization of the rapid delivery of hydrogen peroxide to the surface, and subsequently to the interior, of the alginate gel beads (Fig. 6) provides a direct experimental demonstration of effective biocide penetration. Finally, theoretical analysis of unsteady diffusion and diffusion-reaction interactions argue against any significant delay or barrier to antimicrobial delivery.

Similarly, transport limitation of a nutrient leading to a stationary phase population cannot be invoked to explain reduced susceptibility of biofilm in this system. In the case of an obligate aerobe such as $P$ s. aeruginosa, the low solubility of oxygen and the known stoichiometry of aerobic growth ensure that oxygen will be the first substrate to be depleted in the biofilm provided that the carbonaceous substrate concentration exceeds approximately $20 \mathrm{mg}^{-1}$. An order of magnitude calculation of the balance of reaction and diffusion for oxygen in this system showed that the reduction in oxygen concentration at the bead surface would be less than $1 \%$. In summary, our alginate gel bead biofilms are simply too thin and the mass transfer rates between the suspended gel beads and the bulk fluid too fast to give rise to significant transport artifacts of any kind.

Biofilms grown on glass slides were orders of magnitude thicker than alginate gel bead biofilms. Glass slide-grown 
biofilms also exhibited reduced susceptibility to disinfection by both monochloramine and hydrogen peroxide. These biofilms were probably protected by multiple resistance mechanisms, including transport limitation of biocide penetration into the biofilm. It is not possible to perform rigorous transport calculations in this case because the external mass transfer coefficient for this system is not easily estimated. This inability to quantify the transport process is a serious limitation that the glass slide biofilm system shares with most other laboratory model systems for measuring antimicrobial efficacy.

\section{Resistant biofilm phenotype hypothesized}

Previous studies have shown that when cells attach to a surface they undergo physiological and metabolic changes (Davies and McFeters 1988; McFeters et al. 1990; Griffith and Fletcher 1991; Davies, Chakrabarty and Geesey 1993; Vandevivere and Kirchman 1993; Ascon-Cabrera, AsconReyes and Lebeault 1995; Wentland et al. 1996). The work reported in this paper shows that reduced susceptibility of attached Ps. aeruginos a cells to two oxidative biocides should also be recognized as a inherent phenotypic change and not just a transport artifact. Other studies of thin biofilm susceptibility to various antimicrobial agents support this interpretation (e.g. Das et al. 1998), though they lack characterization of the transport processes. If phenotypic changes indeed take place upon cell attachment to a surface, it is natural to wonder to what extent these changes are encoded in the genome. Recent reports are now providing the first glimpse of the genetic basis for biofilm formation (Davies etal. 1993; Davies and Geesey 1995; Davies et al. 1998; McKenney et al. 1998; O'Toole and Kolter 1998; Pratt and Kolter 1998; Stickler et al. 1998; Vidal et al. 1998). We hypothesize that new genes are expressed when bacteria attach to a surface and begin to form a biofilm and that some of the resulting gene products reduce the susceptibility of the cell to antimicrobial agents including oxidative biocides such as monochloramine and hydrogen peroxide.

In practical terms this means that the problem of biofilm control by antimicrobial agents is indeed complex. In addition to overcoming antimicrobial penetration failure and surmounting regions of starved or nutrient-limited cells, we must also cope with an inherently resistant biofilm phenotype. However, the possibility that the biofilm phenotype is genetically determined may foretell of a multitude of new chemotherapeutic targets for controlling biofilm fouling and infections.

\section{ACKNOWLEDGEMENTS}

This work was supported by the Center for Biofilm Engineering at Montana State University, a National Science Foun- dation-sponsored engineering research centre (co-operative agreement ECD-8907039).

We thank Dr Michael Franklin for his development of the GFP expressing Ps. aeruginosa. We also thank Brian VanderVen and Travis Loberg for technical assistance.

\section{REFERENCES}

American Public Health Association, American Water Works Association and Water and Environment Federation (1995) Standard Methods for the Examination of Water and Wastemater. Washington, DC: American Public Health Association.

Ascon-Cabrera, M.A., Ascon-Reyes, D.B. and Lebeault, J.M. (1995) Degradation activity of adhered and suspended Pseudomonas cells cultured on 2,4,6-trichlorophenol, measured by indirect conductivity. Fournal of Applied Bacteriology 79, 617-624.

Bakke, R., Trulear, M.G., Robinson, J.A. and Characklis, W.G. (1684) Activity of Pseudomonas aeruginosa in biofilms: steady state. Biotechnology and Bioengineering 16, 1418-1424.

Brown, M.R.W., Allison, D.G. and Gilbert, P. (1988) Resistance of bacterial biofilms to antibiotics: a growth-rate related effect? Fournal of Antimicrobial Chemotherapy 22, 777-783.

Brown, S.M., Howell, M.L., Vasil, M.L., Anderson, A.L. and Hassett, D.J. (1995) Cloning and characterization of the $\mathrm{katB}$ gene of Pseudomonas aeruginosa encoding a hydrogen peroxideinducible catalase: purification of KatB, cellular localization, and demonstration that it is essential for optimal resistance to hydrogen peroxide. Fournal of Bacteriology 177, 6536-6544.

Cargill, K.L., Pyle, B.H., Sauer, R.L. and McFeters, G.A. (1992) Effects of culture conditions and biofilm formation on the iodine susceptibility of L. pneumophila. Canadian Fournal of Microbiology 38, 423-429.

Chen, C.-I., Griebe, T. and Characklis, W.G. (1993) Biocide action of monochloramine on biofilm systems of Pseudomonas aeruginosa. Biofouling 7, 1-17.

Chen, X. and Stewart, P.S. (1996) Chlorine penetration into artificial biofilm is limited by a reaction-diffusion interaction. Environmental Science Technology 30, 2078-2083.

Cormick, B.P., Valdivia, R.H. and Falkow, S. (1996) FACS-optimized mutants of the green fluorescent protein (GFP). Gene 173, 33-38.

Costerton, J.W., Marrie, T.J. and Cheng, K.-J. (1985) Phenomena of bacterial adhesion. In Bacterial Adhesion ed. Salvage, D.C. \& Fletcher, M. pp. 3-43. New York, NY: Plenum Press.

Crank, J. (1956) The Mathematics of Diffusion. Oxford: Clarendon.

Das, J.R., Bhakoo, M., Jones, M. and Gilbert, P. (1998) Changes in the biocide susceptibility of Staphylococcus epidermidis and Escherichia coli cells associated with rapid attachment to plastic surfaces. Fournal of Applied Microbiology 84, 852-858.

Davies, D.G., Chakrabarty, A.M. and Geesey, G.G. (1993) Exopolysaccharide production in biofilms: substratum activation of alginate gene expression by Pseudomonas aeruginosa. Applied and Environmental Microbiology 59, 1181-1186.

Davies, D.G. and Geesey, G.G. (1995) Regulation of the alginate biosynthesis gene alg $\mathrm{C}$ in Pseudomonas aeruginosa during biofilm development in continuous culture. Applied and Environmental Microbiology 61, 860-867. 
Davies, D.G. and McFeters, G.A. (1988) Growth and comparative physiology of Klebsiella oxytoca attached to granular activated carbon particles and in liquid media. Microbial Ecology 15, 165175 .

Davies, D.G., Parsek, M.R., Pearson, J.P., Iglewski, B.H., Costerton, J.W. and Greenberg, E.P. (1998) The involvement of cellto-cell signals in the development of a bacterial biofilm. Science 280, 295-298.

de Beer, D., Srinivasan, R. and Stewart, P.S. (1994) Direct measurement of chlorine penetration into biofilms during disinfection. Applied and Environmental Microbiology 60, 4339-4344.

Dibdin, G.H., Assinder, S.J., Nichols, W.W. and Lambert, P.A. (1996) Mathematical model of bata-lactam penetration into a biofilm of Pseudomonas aeruginosa while undergoing simutaneous inactivation by released beta-lactamases. Fournal of Antimicrobial Chemotherapy 38, 757-769.

Franklin, M.J. and Ohman, D.E. (1993) Identification of alg $F$ in tha alginate biosynthetic gene cluster of Pseudomonas aeruginosa which is required for alginate acetylation. Fournal of Bacteriology $175,5057-5065$.

Gilbert, P. and Brown, M.R.W. (1995) Mechanisms of the protection of bacterial biofilms from antimicrobial agents. In Microbial Biofilms ed. Lappin-Scott, H. \& Costerton, J.W. pp. 118130. Cambridge: Cambridge University Press.

Griffith, P.C. and Fletcher, M. (1991) Hydrolysis of protein and model dipeptide substrates by attached and nonattached marine Pseudomonas sp. strain NCIMB 2021. Applied and Environmental Microbiology 57, 2186-2191.

Hoben, H.J. and Somasegaran, P. (1982) Comparison of the pour, spread, and drop plate methods for enumeration of Rhizobium spp. in inoculants made for presterilized peat. Applied and Environmental Microbiology 44, 1246-1247.

Holloway, B.W. (1955) Genetic recombination in Pseudomonas aeruginosa. Fournal of General Microbiology 13, 572-581.

Klothoff, I.M. and Sandell, E.B. (1952) Textbook of Quantitative Inorganic Analysis. New York, NY: The McMillan Company.

Liu, X., Roe, F., Jesaitis, A. and Lewandowski, Z. (1998) Resistance of biofilms to the catalase inhibitor 3-amino-1,2,4-triazole. Biotechnology and Bioengineering 59, 156-162.

Matthysse, A.G.S., Stretton, S., Dandie, C., McClure, N.C. and Goodman, A.E. (1996) Construction of GFP vectors for use in Gram-negative bacteria other than Escherichia coli. FEMS Microbiological Letters 145, 87-94.

McFeters, G.A., Egli, T., Wilberg, E., Alder, A., Schneider, R., Suozzi, M. and Giger, W. (1990) Activity and adaptation of nitrilotriacetate (NTA) -degrading bacteria: fields and laboratory studies. Water Research 24, 875-881.

McKenney, D., Hubner, J., Muller, E., Wang, Y., Goldman, D.A. and Pier, G. (1998) The ica locus of Staphylococcus epidermidis encodes production of the capsular polysaccharide adhesin. Infection and Immunity 66, 4711-4720.

Miles, A.A. and Misra, S.S. (1938) The estimation of the bactericidal power of blood. Fournal of Hygiene, Cambridge 38, 732-749.
O’Toole, G.A. and Kolter, R. (1998) Flagellar and twitching motility are necessary for Pseudomonas aeruginosa biofilm development. Molecular Microbiology 30, 295-304.

Perry, R.H. and Chilton, C.H. (1973) Chemical Engineer's Handbook. New York, NY: McGraw-Hill.

Pratt, L.A. and Kolter, R. (1998) Genetic analysis of Escherichia coli biofilm formation: roles of flagella, motility, chemotaxis and type I pili. Molecular Microbiology 30, 285-293.

Sanderson, S.S. and Stewart, P.S. (1997) Evidence of bacterial adaptation to monochloramine in Pseudomonas aeruginosa biofilms and evaluation of biocide action model. Biotechnology and Bioengineering 56, 201-209.

Smidsrød, O. and Skjåk-Bræk, G. (1990) Alginate as immobilization matrix for cells. TIBTECH 8, 71-78.

Stewart, P.S. (1996) Theoretical aspects of antibiotic diffusion into microbial biofilms. Antimicrobial Agents and Chemotherapy 40, 2517-2522.

Stewart, P.S., Grab, L. and Diemer, J.A. (1998) Analysis if biocide transport limitation in an artificial biofilm system. Fournal of Applied Microbiology 85, 495-500.

Stewart, P.S. and Raquepas, J.B. (1995) Implications of reactiondiffusion theory for the disinfection of microbial biofilms by reactive antimicrobial agents. Chemical Engineering Science 50, 3099-3104.

Stickler, D.J., Morris, N.S., McLean, R.J.C. and Fuqua, W.C. (1998) Biofilm on indwelling urethral catheters produce quorumsensing signal molecules in situ and in vitro. Applied and Environmental Microbiology 64, 3486-3490.

U.S. and Food and Drug Administration. (1984) Bacteriological Analytical Manual. Washington, DC: US Food and Drug Administration.

Vandevivere, P. and Kirchman, D.L. (1993) Attachment stimulates exopolysaccharide synthesis by a bacterium. Applied and Environmental Microbiology 59, 3280-3286.

Vidal, O., Longin, R., Prigent-Combaret, C., Dorel, C., Hooreman, M. and Lejeune, P. (1998) Isolation of an Escherichia coli K12 mutant strain able to form biofilms on inert surfaces: involvement of a new ompR allele that increases curli expression. Fournal of Bacteriology 180, 2442-2449.

Wentland, E.J., Stewart, P.S., Huang, C.-T. and McFeters, G.A. (1996) Spatial variations in growth rate within Klebsiella pneumoniae colonies and biofilm. Biotechnological Progress 12, 316321.

Westrin, B.A. and Axelsson, A. (1991) Diffusion in gels containing immobilized cells: a critical review. Biotechnology and Bioengineering 38, 439-446.

Xu, K.D., Stewart, P., Xia, F., Huang, C.-T. and McFeters, G.A. (1998) Spatial physiological heterogeneity in Pseudomonas aeruginosa biofilm is determined by oxygen availability. Applied and Environmental Microbiology 64, 4035-4039.

Xu, X., Stewart, P.S. and Chen, X. (1996) Transport limitation of chlorine disinfection of Pseudomonas aeruginosa entrapped in alginate beads. Biotechnology and Bioengineering 49, 93-100. 